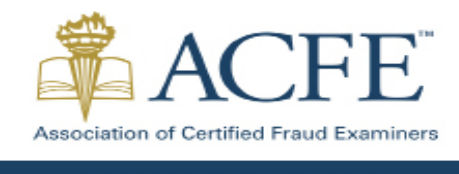

Indonesia Chapter \#111
Asia Pacific Fraud Journal

E-ISSN: 2502-695X, ISSN: 2502-8731

Volume 5, Nomor 2 (July-December) 2020

http://apfjournal.or.id/index.php/apf

\title{
RELIGIOSITY MODERATION ON THE EFFECT OF WHISTLEBLOWING INTENTION AND FRAUD TENDENCY
}

\author{
Veni Nopeanti, ${ }^{\circledR}$ Tarjo, Bambang Haryadi \\ Universitas Trunojoyo Madura, Indonesia
}

\author{
ARTICLE INFORMATION \\ Article History: \\ Received Dec 2, 2020 \\ Revised Dec 16, 2020 \\ Accepted Dec 26, 2020 \\ DOI: \\ 10.21532/apfjournal.v5i2.169
}

\begin{abstract}
ABTRACT
This study examined the effect of whistleblowing intention on fraud tendency and the role of religiosity as a moderating variable of the effect of whistleblowing intention on fraud tendency in higher education institutions. The sample in this research was finance staff at State Universities in East Java. The research data were obtained by distributing questionnaires directly to the respondents. The methods used for data analysis in this research were simple linear regression and Moderated Regression Analysis (MRA). The results show that whistleblowing intention has an effect on fraud tendency. Besides, religiosity is also proven to be a moderating variable of whistleblowing intention effect on fraud tendency in higher education institutions.

Keyword: Whistleblowing Intention, Religiosity, Fraud Tendency, Higher Education.
\end{abstract}

\section{INTRODUCTION}

There are still many practices of education fund fraud in Indonesia. During 20062015, education fund fraud caused state losses of IDR 1.3 trillion with a total of 425 corruption cases involving 618 perpetrators throughout Indonesia (ICW, 2016). The survey conducted by ICW also shows that $59 \%$ of respondents had experienced extortion in the higher education sector (ICW, 2017). The rise of fraud cases in the world of higher education is of course very concerning - considering that higher education institutions should be a place to form a generation that is clean from fraud. The existence of fraudulent practices in the world of higher education also raises the risk that students and employees believe that someone's success does not come from hard work, but is the result of fraudulent acts (Chapman and Lindner 2016). Cressey's Fraud Triangle Theory states that in general, fraud occurs because of three

\footnotetext{
${ }^{\triangle}$ Corresponding author :

Email : tarjo@trunojoyo.ac.id
}

things, namely pressure, opportunity, and rationalization (Rachmanta and Ikhsan 2014).

Opportunities for fraud can be managed by exercising strong internal controls to prevent members of the organization from abusing their power (Syamsudin 2015). ACFE (2016) shows that $51.5 \%$ of the reporting violations are made by members of the organization. This requires the application of a whistleblowing system in an organization as part of its internal control. The government also needs to play an active role in reducing the opportunity for an organization to commit fraud, one of which is by requiring organizations to have a whistleblowing policy (Oktaviani, Karyawati, and Arsyad 2014). Apart from functioning as prevention, whistleblowing can be used to detect fraud (Johansson and Carey 2016). Whistleblowing can be defined as reports of an error or misconduct to the authorities (Near and Miceli 1985). Smaili

Association of Certified Fraud Examiners (ACFE) Indonesia Chapter Page. 266-276 
and Arroyo (2017) in their research, link whistleblowing with the Fraud Triangle Theory, namely pressure, opportunity, and rationalization where these three factors collectively encourage a person to take an action of whistleblowing acts. Indriasih (2016) research shows that there is an effect between whistleblowing and fraudulent financial statements. This research is different from the results of research conducted by Wibowo and Wijaya (2009) which indicated that the Fraud Early Warning System (FEWS), which includes a whistleblowing component, had no effect on business activities that lead to fraud.

The different results of this research are possible because there are other factors that influence the relationship between whistleblowing and fraud. In this research, the religiosity variable was proposed to explain these factors. Research conducted by (Pamungkas 2014) shows that religiosity has a significant effect on the tendency of accounting fraud. A person who practices religion has an ethical foundation to help guide them in making good decisions. Furthermore, they find it more difficult to rationalize illegal acts (fraud) as acceptable (Albrecht 2006). In other words, a person who is religious rationally will not commit an act of deviance because they know what they are doing is wrong and results in sin, so belief in religion can prevent someone from committing fraud (Wicaksono and Urumsah 2017). Religiosity also has a positive effect on whistleblowing intention (Gocke 2016). This may imply that the higher a person's religiosity level, the greater their desire to report fraud/fraudulent acts. Religiosity is a person's belief in religion and is applied in his daily behavior. In this study, religiosity is a moderating variable, which can weaken or strengthen the relationship between whistleblowing intention and the tendency of fraud. On the basis of the aforementioned background, this study would look at the effect of whistleblowing intention with religiosity as a moderating variable on the tendency of fraud in the higher education sectors.

\section{LITERATURE REVIEW AND HYPO- THESIS}

\section{Fraud}

Fraud is an action taken by internal or external parties with the aim of hiding something. These actions are usually illegal and indicate violations, such as misstatements, policy violations, or unethical acts. This action causes harm to the organization, company value, organization reputation, or unauthorized gain received by someone or another person (Vona 2008).

Furthermore, Indonesian Accountants Association (2001)defines fraud, in this case is fraudulent financial statements, as misstatement or intentional omission of amounts in financial statements in order to deceive users of financial statements. Fraud in financial statements can be in the form of (a) manipulation, falsification, or changes in accounting records or supporting documents that are the source of data for the presentation of financial statements (b) misrepresentations in or omission of significant events, transactions, or information (c) deliberate misapplication of accounting principles relating to amounts, classifications, presentation methods, or disclosures.

\section{Whistleblowing Intention and Fraud Tendency}

A whistleblower or fraud reporter is an employee of the organization itself (internal party), but it is also possible that the reporter comes from an external party (customers, suppliers, the public). Whistleblowers should provide clear evidence, information, instructions, or indications of the occurrence of the reported violations so that they can be traced or followed up. Without adequate information from the reporting party, the report will be difficult to follow up (KNKG 2008)

If whistleblowing is seen as a process, it contains four elements (Miceli and Near 1985) namely: whistle-blowers, actions or complaints about whistleblowing, parties who receive complaints from organizations 
and - organizations where the complaint is filed. Whistleblowing can be defined as disclosure by members of an organization (past or present) about illegal, immoral, or invalid practices under the control of their organization, to the leaders of other organizations or institutions that can take action on these violations (Near and Miceli 1985). Furthermore, KNKG (2008) defines whistleblowing as an act of disclosing violations or disclosing actions that are against the law, unethical/immoral actions or other actions that can harm the organization or stakeholders, which are committed by employees or leaders of the organization to the leaders of other organizations or institutions that can take action on these violations. This disclosure is generally done in secret (confidential). Disclosure of violations must be made in good faith and not constitute a personal complaint against a particular company policy or based on bad will/slander. Whistleblowing can also be defined as an intentional non-mandatory act in the form of disclosure to public records and made by a person who has special access to data or information of an organization, about something illegal or other errors in the form of actual, suspected or anticipated events and is under the control of the organization, to external entities that have the potential to correct the violation (Jubb 1999).From several definitions of whistleblowing above, it can be concluded that whistleblowing is disclosure of the existence of violation acts or disclosure of actions that are against the law, unethical/ immoral or other actions that can harm the organization and stakeholders.

Whistleblowing is also a system that can be used to detect fraud. With a proper whistleblowing system, it will reduce the reluctance of whistleblowers to report an error or misconduct to the authorities (KNKG 2008). Basically, fraud is something that is deliberately hidden. The whistleblowing system helps to detect fraud by encouraging potential whistleblowers to report fraud (Johansson and Carey 2016). According to ACFE (2016), tips (reporting on fraud) are in the top rank $(43.5 \%)$ as the most commonly used method to detect fraud in an organization, in this case employees are the ones who tipped the most (51.5\%). Employees usually focus more on reporting mechanisms within the organization.

Survey conducted by (Bashir et al. 2011) shows that as many as 1,446 respondents knew of an act of violation, however 92\% of those who knew about the violation remained silent and did not report it to the authorities. Reluctance to report violations known to employees can be overcome through the implementation of an effective, transparent, and responsible whistleblowing system. This system is expected to increase the level of employee participation in reporting violations (KNKG 2008). With the application of whistleblowing, it is hoped that employees will dare to disclose known violations, because with the whistleblowing system, their rights as whistleblowing agents will be guaranteed confidentiality and their rights as witnesses are protected.

Several studies linking the effect of whistleblowing to the occurrence of violations (fraud) in organizations have also been carried out by Dyck, Morse, and Zingales (2010). They examined some of the impact of supervision carried out by auditors, analysts, investors, clients and suppliers, employees, lawyers and the media on the organization, where the supervision (whistleblowing) is successful in uncovering the occurrence of errors in financial statements. In the sample of research cases of fraud between 1996 and 2004, whistleblower by employees is the most common method of finding cases of fraudulent financial statements. Research conducted by Wilde (2013) also examined the relationship between employee whistleblowing demands and financial misreporting behavior on companies in the United States from 2003 to 2007. The data for this study were taken from the US Occupational Safety and Health Administration (OSHA). The results of this study indicate that companies that are 
subject to whistleblowing demands from their employees are less likely to make financial reporting errors. Furthermore, research conducted by Indriasih (2016) which aimed to determine the effect of whistleblowing effectiveness on financial statementfraud reveal that the effectiveness of whistleblowing effects on fraudulent financial statements. The more effective whistleblowing will reduce fraudulent financial statements. The same thing was also seen in Maulidi (2016), research which results show that the whistleblowing system minimizes and reduces financial reporting errors.

The large amount of research on whistleblowing intention rather than actual whistleblowing is based on the impossibility and difficulty of investigating unethical behavior (fraud) in organizations with direct observation. For this reason, many studies use whistleblowing intention as their operational variable (Victor et al., 1993). Thus, intention is the best prediction of an actual action (Chiu 2011). Research conducted by Victor et al. (1993), also shows that one's behavioral intention correlates with actual reporting of unethical behavior. Based on this, the hypothesis of this study is:

H1: Whistleblowing intention affects the tendency of fraud.

Whistleblowing Intention, Religiosity, and Fraud Tendency

The impact of religion on social and economic life has long been a matter of debate. Currently, some studies are concerned with behavior aimed at exploring the relationship between religious beliefs and ethics in business (Aydemİr and Eğllmez 2010). Religiosity can be defined as belief in God with commitment and following certain principles established by God (McDaniel and Burnett 1990). Religiosity or a religious commitment is defined as a person's belief in values, obedience and religious behavior in everyday life (Worthington, Everett L. 1988).
Furthermore, religiosity in the concept of the Muslim Religiosity-Personality Inventory (MRPI) can be understood as two main things, namely Islamic Worldview and Religious Personality. Religious Personality includes behavior, motivation, attitudes, and emotions that reflect Islamic teachings and commands. Religious Personality is represented by statements related to special rituals or worship that reflect a person's direct relationship with God and daily mu'amalat, or religious guidance that guides behavior towards family, fellow humans and other creations (Krauss et al., 2006). Of the two main things in the MRPI, Religious Personality is a religiosity scale that is suitable to be adapted in several religions. Religious Personality is the embodiment of the religious view of God in one's behavior as taught by all religions. It refers to a variety of behavioral actions, namely actions towards God; actions against fellow humans; actions against nonhumans (animals, environment, etc.); and actions against oneself (Krauss et al., 2007).

Religiosity is considered to have contributed to the reduction in the risk of fraud behavior and attitude in several ways. First, religion has a way in such a way as to prevent someone from having deviant beliefs and behavior (for example: don't steal). Religion has also provided a negative definition of deviance. Furthermore, religion prevents deviations from occurring and provides an anti-deviant attitude through threats of eternal punishment, such as time spent in hell. Second, religion can reduce crime by socializing with friends. Religion influences a religious person in choosing people who have an anti-deviant attitude and have similar beliefs to be friends (Baier and Wright, 2001).

Religiosity within a person will also affect whistleblowing intention. Research conducted by (Puni, Agyemang, and Asamoah 2016) shows that the intention in a person to take an action of whistleblowing is influenced by the level of religiosity they 
have. Religiosity can be assumed that it can prevent someone from doing unethical acts because in religion there is a prohibition against committing unethical acts and considers it a sin. One's level of religiosity will be different from others. The higher the level of a person's religiosity, the less they will commit acts of fraud. So it can be concluded that individuals who have good faith tend to stay away from cheating/ fraudulent actions (Wicaksono and Urumsah, 2016). For this reason, religiosity will affect whistleblowing intention and the tendency to fraud. Based on this, the hypothesis of this study is:

$\mathrm{H} 2$ : Religiosity is moderating the effect of whistleblowing intention on the tendency to fraud.

\section{METHODS}

\section{Methods and Data Collection}

The approach used in this research was quantitative methods. The data were obtained by distributing questionnaires directly to 145 educational staff, namely financial staff at PTNBH in East Java using the purposive sampling method. The criteria for respondents in question are education personnel in the financial division of the budget, treasury, reporting, and accounting subsections, as well as the treasurer.

Measurement and Operational Definition of Variables

The questionnaire in this study consisted of 30 items. Respondents were asked to choose several statements on a Likert scale consisting of five points, namely $1=$ strongly disagree to $5=$ strongly agree. The questionnaire used to measure whistleblowing intention (7 items) was adapted from (Park, Rehg, and Lee 2005). A high score indicates a higher intention to report wrongdoings in the organization. Meanwhile, the questionnaire used to measure religiosity (16 items) was adapted from (Krauss, Hamzaah and Idris 2007); a high score indicates a higher level of religiosity among respondents. The questionnaire used to measure tendency of fraud was adapted from (Thoyibatun 2009), a high score indicates a higher tendency to fraud.

\section{Hypothesis Testing}

In testing hypothesis one, namely whether whistleblowing intention affects the tendency of fraud, a simple linear regression test was used, while to test the second hypothesis, namely to determine whether religiosity is a moderating variable of the effect of whistleblowing intention on the tendency of fraud, moderated regression analysis (MRA) was used. MRA is a special application of multiple linear regression where the regression equation contains elements of interaction (multiplication of two or more independent variables) (Liana, 2009). The relationship equation model between the variables used is as follows:

$\gamma=\alpha+\beta 1 X 1+e$

$\gamma=\alpha+\beta 1 X 1+\beta 2 X 1 X 2+e$

Where:

$Y=$ tendency to fraud

$\alpha=$ constant

$\beta=$ regression coefficient

$\mathrm{X} 1 \mathrm{=}$ whistleblowing intention

$\mathrm{X} 2$ = religiosity

Figure 1. Research Model

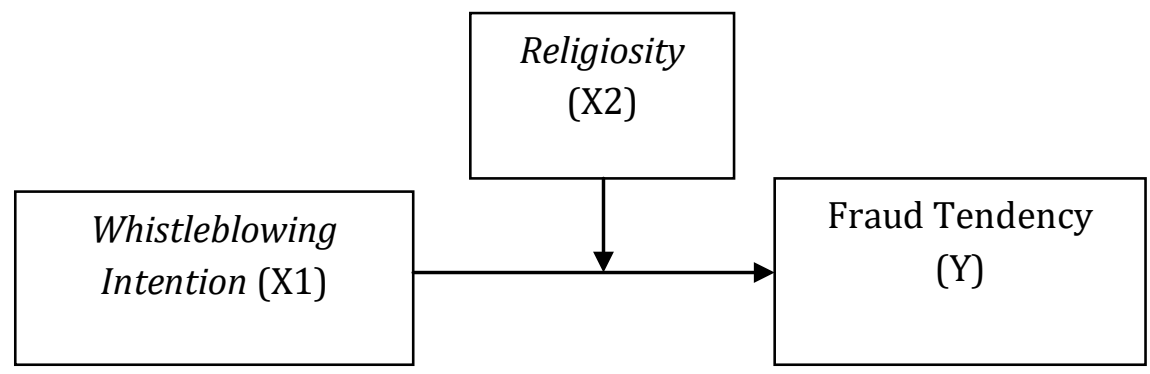


Table 1. Operational Definition of Variables

\begin{tabular}{|c|c|c|c|}
\hline No. & Variable & Definition & Question indicator \\
\hline 1. & $\begin{array}{l}\text { Whistleblowing } \\
\text { Intention (Park, Rehg, } \\
\text { and Lee 2009). }\end{array}$ & $\begin{array}{l}\text { Disclosure by members of the } \\
\text { organization of illegal, immoral, } \\
\text { or invalid practices under the } \\
\text { control of their organization, to } \\
\text { the leaders of other organizations } \\
\text { or institutions that can take action } \\
\text { on these violations }\end{array}$ & $\begin{array}{l}\text { A case consisting of seven } \\
\text { statement items to measure } \\
\text { respondents' perceptions of } \\
\text { whistleblowing intention. }\end{array}$ \\
\hline 2. & $\begin{array}{l}\text { Fraud tendency } \\
\text { (Thoyibatun et al. } \\
\text { 2009) }\end{array}$ & $\begin{array}{l}\text { Misstatements arising from } \\
\text { improper treatment of assets } \\
\text { and misstatement or intentional } \\
\text { omission of amounts or } \\
\text { disclosures in financial statements } \\
\text { in order to deceive users of } \\
\text { financial statements }\end{array}$ & $\begin{array}{l}\text { Misrepresentation } \\
\text { Incorrect application } \\
\text { Asset embezzlement } \\
\text { Misuse of money/ goods } \\
\text { receipts }\end{array}$ \\
\hline 3. & $\begin{array}{l}\text { Religiosity } \\
\text { (Krauss, Hamzah and } \\
\text { Idris 2007; Othman } \\
\text { and Hariri 2012) }\end{array}$ & $\begin{array}{l}\text { The embodiment of one's } \\
\text { religious views and awareness } \\
\text { of the existence of God in one's } \\
\text { behavior which refers to a variety } \\
\text { of behaviors and actions }\end{array}$ & $\begin{array}{l}\text { Personality } \\
\text { Attitude } \\
\text { Religious practice } \\
\text { Human relationship }\end{array}$ \\
\hline
\end{tabular}

\section{RESULT AND DISCUSSION Respondent Demographics}

The number of questionnaires distributed in this study was 145 questionnaires and 118 questionnaires were returned. Of the 118 returned questionnaires, there were 3 questionnaires that could not be processed because the respondents did not fill out the questionnaire completely. Thus, the total number of processed data was 115 questionnaires.

From the distribution of respondents, it can be seen that female respondents have a greater percentage of $59.1 \%$ or 68 respondents. Male respondents have a percentage of $40.9 \%$ or 47 respondents. Respondents with the latest S1 education level have the largest percentage, namely $68.7 \%$ or 79 respondents, while $11.3 \%$ or 13 respondents with S2 education level and for respondents who had Diploma (D3) education were $10.4 \%$ or 12 respondents. Meanwhile respondents who had high school education level have the lowest percentage, namely $9.6 \%$ or 11 respondents

For the age group, respondents who were more than 35 years old have the highest percentage, namely $47.8 \%$ or 55 respondents. Respondents who were between 25 and 35 years old have a percentage of $46.1 \%$ or 53 respondents. Meanwhile, respondents with the age group less than 25 years have the smallest percentage, namely $6.1 \%$ or only 7 respondents.

Most of the respondents' working period is between 5-10 years, namely 39 people or $13 \%$. Meanwhile, 36 people or $31.3 \%$ has worked more than 15 years. Then, respondents with a working period of $11-15$ years were 25 people or $21.7 \%$. Respondents who have a working period of less than five years have the least percentage namely of $13.0 \%$ or 15 people.

\section{Reliability Test}

Reliability test is used to determine the consistency of the measuring instrument, whether the measuring instrument (questionnaire) used is reliable if it is used several times to measure the same object, and whether it will produce the same data if the measurement is repeated. Reliability testing is said to be valid if the Cronbach alpha value is greater than 0.60 . 
Table 2. Reliability Test

\begin{tabular}{ll}
\hline Variable & Cronbach Alpha \\
\hline Whistleblowing & 0.757 \\
Intention & \\
Religiosity & 0.782 \\
Fraud Tendency & 0.762 \\
\hline \multicolumn{2}{l}{ Source: Process Data, 2020}
\end{tabular}

From table 2 above it can be seen that the value Cronbach alpha for all variables greater than 0.60 . It can be concluded that the questionnaire in this study is reliable and can be used as a measuring tool in research.

\section{Whistleblowing Intention and Fraud Tendency}

To test the first hypothesis, whether there is an effect between the independent variable, whistleblowing intention, and the dependent variable, the tendency of fraud, a simple linear regression analysis was used.

From table 3 above, it can be explained that the parameter coefficient value of -0.479 indicates a negative value, which means that whistleblowing intention has a negative effect on the tendency of fraud. This shows that the higher whistleblowing intention, the lower a person's tendency to commit fraud. From the results of hypothesis testing, it can be seen that the $\mathrm{t}$-value for the whistleblowing intention variable is 5.066 . This value is greater than the t-table value of 1.98 (5.066> 1.98) with a significance value of $0.000(0.000$ $<0.05)$, thus the first hypothesis $\left(\mathrm{H}_{1}\right)$ is accepted and it can be concluded that whistleblowing intention has a significant effect on the tendency of fraud. The value of Adjusted R Square $\left(R^{2}\right)$ in table 2 is 0.206 which indicates that the tendency of fraud can be explained by the whistleblowing intention variable, which is $20.6 \%$, while the rest $79.4 \%$ is influenced by other variables.

Whistleblowing is an act of reporting against a violation in an organization. A person can prevent fraud or wrongdoing in an organization by whistleblowing against existing violations in the organization (Miceli and Near 1985). The results of this study indicate that whistleblowing intention affects the tendency of fraud. The higher a person's desire to report a violation, the less likely they will commit fraud. With the intention of a person to do whistleblowing, they consider that violations or acts of fraud in an organization are unacceptable. For that they also do not commit fraud or violations to the organization. This result is also in accordance with the research conducted by Indriasih (2016), which shows that whistleblowing has an effect in reducing fraudulent financial statements. Similar results are also shown in (Maulidi 2016) research in which it shows that the whistleblowing system minimizes and reduces financial reporting errors.

Lee and Fargher (2015), in their research on whistleblowing state that with the support of an ethical environment and good governance it can help strengthen whistleblowing policies so that later it can prevent fraud. Furthermore, the results of this study are also in accordance with research by Dyck, Morse, and Zingales (2010) which shows that whistleblowing is an effective tool for detecting fraud in an organization.

\section{Whistleblowing Intention, Religiosity, and Fraud Tendency}

To test the second hypothesis, namely whether religiosity is a moderating variable of whistleblowing intention on the

Table 3. Hypothesis Test of Whistleblowing Intention and Fraud Tendency

\begin{tabular}{llll}
\hline Variable & Coefficient & $\mathrm{t}$ & Significance \\
\hline Constant & 27.536 & 10.865 & 0.000 \\
Whistleblowing intention & -0.479 & -5.066 & 0.000 \\
Adjusted R Square & & & 0.206 \\
\hline
\end{tabular}

Source: Process Data, 2020 
Asia Pacific Fraud Journal, 5(2) July-December 2020: 266-276 | 273

Table 4. Hypothesis Test for Whistleblowing Intention, Religiosity, and Fraud Tendency

\begin{tabular}{llll}
\hline Variable & Coefficient & $\mathrm{t}$ & Significance \\
\hline Constant & 9.272 & 9.683 & 0.000 \\
Whistleblowing intention & 1.167 & 2.603 & 0.011 \\
Whistleblowing intention* Religiosity & -1.047 & -4.783 & 0,000 \\
Adjusted R Square & & & 0.306 \\
\hline
\end{tabular}

Source: Process Data, 2020

tendency of fraud, a moderated regression analysis is used.

From table 4 above, it can be explained that the value of Adjusted $\mathrm{R}$ Square $\left(\mathrm{R}^{2}\right)$ is 0.306 , meaning that $30.6 \%$ of the fraud tendency variable can be explained by the independent variable, whistleblowing intention, and the moderation between whistleblowing intention and religiosity. The rest, namely $69.4 \%$, is explained by other variables. From the results of testing the second hypothesis, it can be seen that the $t$-count value for the moderating variable religiosity on whistleblowing intention to the tendency of fraud is 4.783 . This value is greater than the t-table value $(4.783>1.98)$ with a significance value of $0.000(0.000<0.05)$, thus the second hypothesis $\left(\mathrm{H}_{2}\right)$ is accepted and it can be concluded that religiosity is a moderating variable on the effect of whistleblowing intention on the tendency to fraud.

The results of this study indicate that religiosity moderates the effect of whistleblowing intention on fraud. With the high level religiosity, it will increase a person's desire to do whistleblowing and reduce the tendency of fraud. Conversely, the interaction of low whistleblowing intention and low religiosity will result in a high tendency for fraud. For this reason, religiosity will affect the relationship between whistleblowing intention and the tendency to fraud.

This is in line with research conducted by Gocke (2016) in which it reveals that whistleblowing intention is influenced by the level of religiosity. Puni, Agyemang, and Asamoah (2016) also state that the level of religiosity affects a person's intention to report a fraud. Singhapakdi et al., (2013) state that individual behavior can be influenced by religiosity. Highly religious people tend to view unethical behavior as more negative than that of religious people because they think unethical behavior is sinful. Therefore, religiosity can create moral courage which can give a person the ability to make more ethical decisions in difficult circumstances. As a result, a person whose religiosity level is high will tend to report unethical situations (fraud) more often than their colleagues.

Religiosity is also considered to be able to reduce the occurrence of irregularities because there are various coping mechanisms (for example, by praying, meditating, believing in a happy life after death) that will reduce deviant responses to a stressful life. People with high levels of religiosity tend to experience shame when they commit deviant actions, thus it will reduce the crime rates (Stack and Kposowa, 2006). Besides, there is also the assumption that people with higher levels of religiosity will see the world through a religious perspective, and thus they will integrate religious values throughout most of their life (Worthington, 1988).

\section{CONCLUSION}

This study aimed to determine whether there is an effect between whistleblowing intention on the tendency of fraud and religiosity as a moderating variable. Based on the results of the research that has been done, it can be concluded that whistleblowing intention affects the tendency of fraud. The higher a person's desire to report violations in the organization, the lower the desire to commit fraud is. The existence of whistleblowing creates 
reluctance to commit fraud. Religiosity also moderates the effect of whistleblowing intention on the tendency to fraud. A high level of religiosity in a person makes the desire to report fraud in the organization so that it will reduce the tendency of fraud. The results of this study indicate that whistleblowing intention affects the tendency of fraud. To increase whistleblowing intention of organizational members in higher education, it is necessary to make regulations that can protect whistleblower rights in higher education sector. With this regulation, whistleblowers are not reluctant and afraid to report fraud in the organization. For further research, it is hoped that the next researchers can increase the sample size and not only be limited to education personnel in the financial division of higher education sector, but all financial managers in higher education sector, both educational and non-educational staffs in higher education sector.

\section{REFERENCES}

Association of Certified Global Fraud and Examiners (ACFE). 2016. Report To the Nations. Pp. 1-92.

Albrecht, C. 2006. Journal of Management , Spirituality \& Religion A Comment on Koerber and Neck â€ $€^{\mathrm{TM}} \mathrm{S}$ ( 2006 )'Religion in the Workplace: Implications for Financial Fraud and Organizational Decision Making, no. May 2015:37-41. https://doi. org/10.1080/14766080709518647.

Aydemİr, M, dan Ö. EğIIlmez. 2010. An Important Antecedent of Ethical / Unethical Behavior: Religiosity. Eurasian Journal of Business and Economics 3 (6):71-84.

Baier, C. J., dan B. R. E. Wright. 2001. 'If You Love Me, Keep My Commandments': A Meta-Analysis of the Effect of Religion on Crime. Journal of Research in Crime and Delinquency 38 (1):3-21. https:/ / doi.org/10.1177/002242780 1038001001.
Bashir, S, H R Khattak, A Hanif, dan S N Chohan. 2011. "Whistle-Blowing in Public Sector Organizations: Evidence From Pakistan." American Review of Public Administration $41 \quad$ (3):285-96. https://doi. org/10.1177/0275074010376818.

Chapman, D. W., dan S. Lindner. 2016. Degrees of Integrity: The Threat of Corruption in Higher Education. Studies in Higher Education 41 (2):24768. https://doi.org/10.1080/030750 79.2014.927854.

Chiu, K. 2011. Ethical Intention: Role Judgment and Whistleblowing the Moderating Examining of Locus of Control. Journal of Business Ethics 43 (1):65-74. https://doi. org/10.1023/A:1022911215204.

Dyck, A., A. Morse, dan L. Zingales. 2010. Who Blows the Whistle on Corporate Fraud?. The Journal of Finance 65 (6). Wiley Online Library:2213-53.

Gocke, A. T. 2016. The Effect of Teachers' Spirituality and Ethical Ideology on Their Preference of Reporting WrongdoingsatSchools. International Education Studies 9 (5):85. https:// doi.org/10.5539/ies.v9n5p85.

ICW. Kerugian Negara dari Korupsi Sektor Pendidikan Capai 1,3 Triliun Rupiah. Diakses pada 5 Maret 2018, dari http://www.antikorupsi.org.

ICW.Survei Nasional Anti Korupsi 1. 2017.

Ikatan Akuntan Indonesia. 2001. SA Seksi 316 Pertimbangan Atas Kecurangan Dalam Audit Laporan Keuangan. Standar Profesional Akuntan Publik 312 (70).

Indriasih, D. 2016. The Effect of Whistleblowing Effectiveness, Internal Auditors Competence on Fraudulent Financial Reporting (Survey on All Banks in Indonesia). International Journal of Applied Business and Economic Research 14 (14):841-59. 
Johansson, E., dan P. Carey. 2016. Detecting Fraud: The Role of the Anonymous Reporting Channel. Journal of Business Ethics 139 (2). Springer Netherlands:391-409. https://doi. org/10.1007/s10551-015-2673-6.

Jubb, Peter B. 1999. Whistleblowing: A Restrictive Definition and Interpretation. Journal of Business Ethics 21:77-94. https://doi. org/10.1023/A:1005922701763.

KNKG. 2008. Pedoman Sistem Pelaporan Pelanggaran. KNKG.

Krauss, S. E., A. H. Hamzah, T. Suandi, S. M .Noah, R. Juhari, J. H. Manap, K. A. Mastor, H. Kassan, dan A. Mahmood. 2006. Exploring Regional Differences in Religiosity among Muslim Youth in Malaysia. Review of Religious Research2 47 (3):238-52. https://doi.org/10.1007/S13644-01.

Krauss, S. E., A. Hamzah, dan F. Idris. 2007. Adaptation of A Muslim Religiosity Scale. Review of Religious Research2 49(2) (3):238-52. https:// doi.org/10.1007/S13644-01.

Lee, Gladys, dan Neil Fargher. 2015. Companies' Use of Whistle-Blowing to Detect Fraud : An Examination of Corporate Whistle- Blowing Policies Companies' Use of Whistle-Blowing to Detect Fraud: An Examination of Corporate Whistle-Blowing Policies, no. May 2013. https://doi. org/10.1007/s10551-012-1348-9.

Maulidi, A. 2016. Dealing with Fraudulent Financial Statement in Business Organizations through Whistleblowing System and Staff Awareness of Fraud. no. August.

McDaniel, S. W., dan J. J. Burnett. 1990. Consumer Religiosity and Retail Store Evaluative Criteria. Journal of the Academy of Marketing Science 18 (2):101-12. https:/ / doi.org/10.1007/ BF02726426.
Miceli, M. P, dan J. P. Near. 1985. Characterstics of Organizational Climate and Perceived Wrongdoing Associated with Whistle Blowing Decisions. Personnel Psychology 38 (3):525-44.

Near, J. P., dan M. P. Miceli. 1985. Organizational Dissidence: The Case of Whistle-Blowing. Journal of Business Ethics 4 (1):1-16. https:// doi.org/10.1007/BF00382668.

Oktaviani, Evta, Golrida Karyawati, dan Nurruzahman Arsyad. 2014. Factors Affecting Financial Statement Fraud . November:1939-55.

Pamungkas, I. D. 2014. Pengaruh Religiusitas Dan Rasionalisasi Dalam Mencegah Dan Mendeteksi Kecenderungan Kecurangan Akuntansi. Jurnal Ekonomi Dan Bisnis 15 (2):48-59.

Park, H., M. T. Rehg, dan D. Lee. 2005. The Influence of Confucian Ethics and Collectivism on Whistleblowing Intentions: A Study of South Korean Public Employees. Journal of Business Ethics 58 (4). Springer:387-403.

Puni, A., C. B. Agyemang, dan E. S Asamoah. 2016. Religiosity, Job Status and Whistle-Blowing: Evidence from Micro-Finance Companies in the Ga-East District of the Greater Accra Region of Ghana. Global Journal of Human Resource Management 4 (1):52-64.

Rachmanta, R, dan S. Ikhsan. 2014. Analisis Faktor-Faktor Yang Mempengaruhi Kecurangan (Fraud) Di Sektor Pendidikan Kota Semarang. Accounting Analysis Journal 3 (3).

Smaili, Nadia, dan Paulina Arroyo. 2017. Categorization of Whistleblowers Using the Whistleblowing Triangle." Journal of Business Ethics. Springer Netherlands, 1-23. https://doi. org/10.1007/s10551-017-3663-7. 
276 Veni Nopeanti et al., Religiosity Moderation on the Effect of Whistleblowing Intention

Syamsudin, M. 2015. Understanding Corruption from Behavioral Perspective: A Case Study of Yogyakarta Special Province A View of Corruption in ... Understanding Corruption from Behavioral Perspective: A Case Study of Yogyakarta Special Province. October.

Victor, B., L. K. Trevino, dan D. L. Shapiro. 1993. Peer Reporting of Unethical Behavior: The Influence of Justice Evaluations and Social Context Factors. Journal of Business Ethics 12 (4):253-63. https:/ / doi.org/10.1007/ BF01666528.

Vona, L. W. 2008. Fraud Risk Assessment: Building a Fraud Audit Program. https://doi.org/x148.

Wibowo, dan W. Wijaya. 2009. Pengaruh Penerapan Fraud Early Warning System (FEWS) Terhadap Aktivitas Bisnis Perusahaan. Jurnal Informasi, Perpajakan, Akuntansi Dan Keuangan Publik 4 (2):77-111.
Wicaksono, A. P. dan D. Urumsah. 2017. "Factors Influencing Employees To Commit Fraud in Workplace Empirical Study in Indonesian Hospitals." Asia Pacific Fraud Journal 1 (1):1. https://doi.org/10.21532/ apfj.001.16.01.01.01.

Wilde, J. H. 2013. Citizen Watch in the Accounting Department? Tax and Financial Reporting Responses to Employee Whistleblowing Allegations. Disertasi. Texas A\&M University.

Worthington, E. L., Jr. 1988. Understanding the Values of Religious Clients: A Model and Its Application to Counseling. Journal of Counseling Psychology 35 (2):166-74. https:// doi.org/10.1037/0022-0167.35.2.166. 